\title{
THE DEGREE OF SECRETORY IMMUNOGLOBULIN A IN BURN PATIENTS WITH PROBIOTIC
} THERAPY

\author{
LYNDA HARIANI ${ }^{1 *}$, IRAWAN WAHYUDI ${ }^{2}$, ISWINARNO DOSOSAPUTRO ${ }^{1}$, SJAIFUDDIN NOER M. $^{1}$
}

\begin{abstract}
${ }^{1}$ Department of Plastic Reconstructive Surgery, Dr. Soetomo Hospital, Airlangga University School of Medicine, Surabaya, East Java, Indonesia. ${ }^{2}$ Royal Taruma Hospital, Jakarta, Indonesia. Email: lyndaagus@gmail.com
\end{abstract}

Received: 27 January 2019, Revised and Accepted: 03 March 2019

\section{ABSTRACT}

Background: One of the problems with burn patients is the impairment of host immunity, which makes difficult to treat. In burns, immunoglobulin A has demonstrated to decrease. Immunoglobulin A is the main product of mucous immune system, which increases viral clearance and decreases bacterial adhesion in the intestine. Probiotics consist of living microflora, which control the balance of lactobacilli and bifidobacteria in the intestine. Instead of producing organic component, increasing the acidity of intestine, mucin and bacteriocin, they also activate the intestinal immune system and secretory immunoglobulin A (sIgA). The goal of this study was to propose that regular intake of probiotic might help to improve the mucous immune system, especially sIgA in intestines in burn patients.

Methods: An experimental, double-blind, controlled clinical trial was carried out in 33 burn patients. Those patients were divided into two groups. The first group was given daily probiotic and the second group was given only placebo for 10 days. The treatment began on the $4^{\text {th }}$ day admission, and then, the degree of sIgA was evaluated before treatment and day 14 from fecal specimen.

Results: Significant differences between probiotic and control group were observed $(\mathrm{p}<0.0001)$. The degree of sIgA in the probiotic group increased $61.25 \%$, and in the control group, it decreased to $36.80 \%$.

Conclusion: The mucous immune system, especially sIgA, increases by probiotic intake.

Keywords: Probiotics, Mucous immune system, Secretory immunoglobulin A.

(C) 2019 The Authors. Published by Innovare Academic Sciences Pvt Ltd. This is an open access article under the CC BY license (http://creativecommons. org/licenses/by/4. 0/) DOI: http://dx.doi.org/10.22159/ijap.2019.v11s5.T1017

\section{INTRODUCTION}

Burns will activate a local inflammatory reaction that develops into a systemic reaction by releasing toxins associated with immunologic processes of the body, as a lipoprotein complex (lipid-protein complex, burn toxin) which induces the Systemic Inflammatory Response Syndrome (SIRS) event. Detection of SIRS symptoms and bacteremia are an element for diagnosing sepsis. Some previous studies have noted that the incidence of bacteremia in burns patients is about to occur on the $6^{\text {th }}$ to the $10^{\text {th }}$ day after trauma $[1,2]$. Burn wound infection is the highest incidence of the onset of sepsis compared with other trauma. Because gastrointestinal damage will occur due to splanchnic hypoxia resulting bacteria translocation.

Burn victims' statistical data number in 2000 are 7-8 million people, with a mortality rate of 70.000-80.000 and 500.000-800.000 need of require treatment. In Europe, 2-2.5 million casualties were reported, with death from 20,000 to 25,000 [3,5]. The incidents of burn victims at Dr. Soetomo Hospital in 2007-2008 are 33 patients with IIAB grade and $>20 \%$ of burn, as much as $64 \%$ occured in bacteremia as seen in Table 1 .

Some literature has been shown that bacteria may penetrate the intestinal wall through the lymph channels leading to regional lymph nodes and into the bloodstream. The role of the bacteria translocation on human is not clearly known. It has been demonstrated that the complication of severe infection is generally caused by Pseudomonas, Staphylococcus coagulase-negative bacteria, Candida and Enterococcus. All of these bacteria/fungus is a bacteria which live in the bowel of sepsis patients $[4,6,7]$.

Probiotics are dietary supplements containing life microflora that may be consumed in sufficient measure to provide benefits for the host health. Some mechanisms have been known including regulate the balance of lactobacili and bifidobacteria from intestinal flora by producing organic component, which increase the acidity of the intestinal flora resulting inhibit the growth of various harmfull bacteria, mucin and bacteriocin which acts as a natural antibiotics. This activity plays a role in the immune response by increasing the number of lymphocytes, macrophages and normal cell killer, producing cytokines, Interleukin (IL)-12, IL-10, tumor necrosis factor alpha, interferon gamma and secreting immunoglobulin A (IgA) [8-10].

Currently, probiotics are not only consumed as a drug but also processed as an additive in food products (food additive) or milk and are consumed every day by healthy or sick individuals. However, research is mainly carried out by dairy food producers and more focused on safety when they are consumed in the long term by healthy individuals, and not much about the effectiveness or the immune response was generated by its hosts. Numerous animal studies mention that probiotics may influence the host immune response by increasing the production of secretory immunoglobulin mainly secretory IgA $(\operatorname{sig} A)[11,12]$.

Burns trigger an increase of permeability of the intestinal wall because of reperfusion result in increasing the risk of bacteria translocation and endotoxemia and histological lesions in the mucosa and decreasing levels of IgA immunoglobulin and mucin. Administration of Bifidobacteria preparations may reduce the ratio of the balance of aerobic bacteria and endotoxemia and mucosal lesions and reduce symptoms of digestive disorders such as diarrhea in patients with burns [13-15]. By administering the probiotic preparations will obtain the increased levels of intestinal sIgA significantly in the mice $[16,17]$. A clear mechanism of how probiotics may enhance the mucosal immune response is disputed and needs further research [18]. 


\section{METHODS}

To meet the experimental research design, patients were randomized and divided in the probiotic and placebo group in a double-blind manner. Researchers gave probiotic to the treatment group and placebo to the control group. In this study, we obtained 34 samples, with 17 samples for each group, but the treatment group had one dropout.

It is a double-blind clinical trial pre-test-post-test control group experimental research that was conducted to prove the effect of probiotics on the levels of stool sIgA in patients with burns.

The ratio data in the research variables such as age, extensive burns, and sIgA underwent a normality test using Kolmogorov-Smirnov test of one sample prior to statistics analysis. The test results showed that all of these variables were within normal distribution, so the statistical analysis will use parametric test group.

Homogeneity test for age, sex, and extent of burns was performed on both the groups to explore whether all study subjects were at the same condition at the beginning of the study.

\section{RESULTS AND DISCUSSION}

Fig. 1 shows about sIgA levels in healthy person and in burn patients with probiotic and without probiotic taken from day 4. In Fig. 2 shows about sIgA levels in burn patients given probiotic and without probiotic taken on day 10

The mean levels of sIgA in the group given probiotic were lower than the group not given probiotic. Results of statistical analysis using two independent samples t-test are $p=0.014>\alpha 0.05$, means there is a significant difference in the means of slgA in both groups.

A difference in the mean of sIgA level in the group given probiotic increased $61.25 \%$, while in the group not given probiotic decreased $36.80 \%$. The results of statistical analysis two independent samples t-test are $\mathrm{p}<0.0001$; it implies that there is a significant difference on difference of sIgA levels between day 4 and 10 in the two groups (Table 2)

\section{DISCUSSION}

Double-blind clinical trial experimental study with pre-test-posttest control group had been done to study the effect of probiotics' administration to the level of fecal sIgA in patients with burns. In this study, there were 34 samples with 17 samples in each group, but in the treatment group, there was one patient dropout. The study subjects were matched with the inclusion and exclusion criteria. It had been statistically analyzed that the subject distribution of age, sex, and the extent of the burns were normal, so it could be said the subjects were homogen.

The mean level of sIgA in burns' patient in day 4 was $0.240 \mathrm{mg} / \mathrm{g}$, slightly lower than the level of sIgA in a healthy subject (mean: $0.317 \mathrm{mg} / \mathrm{g}$ ) (Table 1). In severe burns, there was a decrease of IgA, IgG, IgN, and IgE level which occurred in days 2-3 after the trauma. However, from the $t$-test result of two free samples, $\mathrm{p}=0.138$ or more than $\alpha 0.05$, which means there was no significant difference in the mean of sIgA between the two groups.

Table 2 shows that the mean sIgA was increased in group given probiotics in day 4 with a mean of $0.175 \mathrm{mg} / \mathrm{g}$ and in day 10 with a mean of $0.259 \mathrm{mg} / \mathrm{g}$. The result of statistical analysis using paired $t$-test showed that there was a significant difference $(p<0.0001)$. In the group which was not given probiotics, the mean sIgA was $0.301 \mathrm{mg} / \mathrm{g}$ in day 4 , and in day 10 , it decreased to $0.170 \mathrm{mg} / \mathrm{g}(\mathrm{p}=0.004)$.

To compare the change of sIgA level between day 4 and 10 in groups given probiotics and not given probiotics, the difference between sIgA levels was used. The difference of sIgA level in the group given

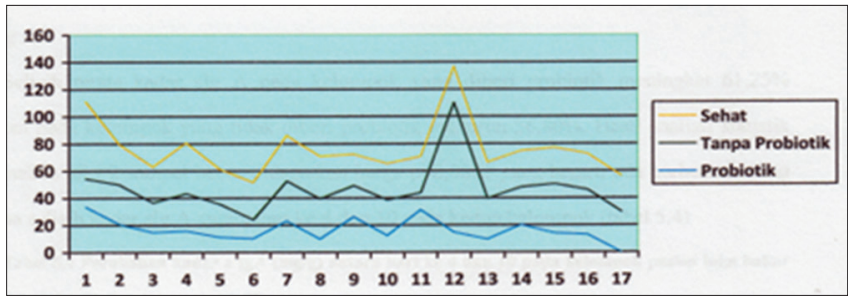

Fig. 1: Chart of secretory immunoglobulin A levels in healthy person, probiotic, without probiotic

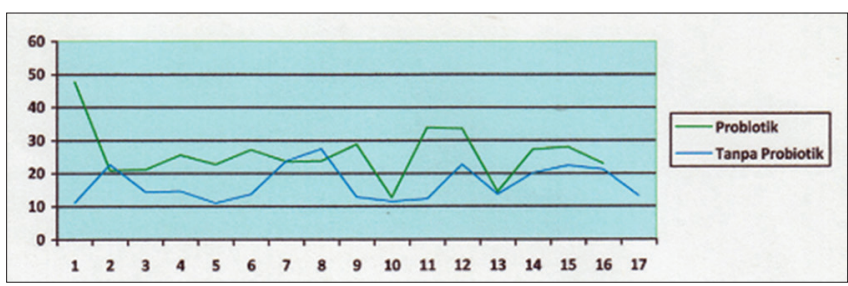

Fig. 2: Chart of secretory immunoglobulin A levels in burn patients given probiotic and without probiotic on day 10

Table 1: Incident of burns $>\mathbf{2 0} \%$ grade IIAB at RSUD Dr. Soetomo

\begin{tabular}{lll}
\hline Years & Number of cases & Mortality (\%) \\
\hline 2006 & 79 & 32 \\
2007 & 69 & 10 \\
2009 & 77 & 12 \\
2010 & 77 & 18 \\
\hline
\end{tabular}

Table 2: Changes in the sIgA levels $(\mathrm{mg} / \mathrm{g})$ between day 4 and day 10 in the group of burn patients given probiotic and without probiotic

\begin{tabular}{llll}
\hline $\begin{array}{l}\text { Secretory } \\
\text { IgA (mg/g) }\end{array}$ & Group & \multirow{2}{*}{$\mathbf{p}$} \\
\cline { 2 - 3 } & $\begin{array}{l}\text { With } \\
\text { prebiotics (n=16), } \\
\text { n (\%) }\end{array}$ & $\begin{array}{l}\text { Without } \\
\text { prebiotics (n=17), } \\
\text { n (\%) }\end{array}$ & \\
\hline Mean & $0.084(61.25)$ & $-0.131(-36.80)$ & $<0.0001$ \\
SD & $0.061(53.48)$ & $0.162(20.98)$ & \\
Minimum & $0.001(0.64)$ & $-0.728(-76.23)$ & \\
Maximum & $0.188(168.25)$ & $-0.002(-1.41)$ & \\
\hline
\end{tabular}

SD: Standard deviation, sIgA: Secretory immunoglobulin A

probiotics was decreased to $36.80 \%$. Statistical analysis using $t$-test in two free samples showed $\mathrm{p}<0.0001$, which showed that there was a significant difference between sIgA levels in days 4 and 10 in the two groups (Table 2).

\section{CONCLUSION}

This study used probiotics latent product which consists of mixed bacteria with the composition of Lactobacillus bulgaricus, Bifidobacteria brave, Bifidobacterium longum, and Streptococcus thermophilus which were Gram-positive bacteria. Those materials had been chosen as treatment regimen because those products consisted of probiotic bacteria strains which had been tested in many studies for their benefit as mucosal immunomodulator [19-21]. By using multistrain probiotics, a synergic modulation effect was expected. In this study, probiotic strain which had more roles in increasing immunoglobulin synthesis was not known. Ideally, study using some single strains had to be done, so it could prove which probiotic strain that had more roles. The reason of the product usage is because this product could be easily found in the market. The probiotic mechanism to increase intestinal sIgA level which was represented by fecal examination in this study was not done. 
However, some literatures suggested that peptidoglycan in the cell wall of the probiotic bacteria would play a role as an antigen in intestinal lumen which stimulate intestinal mucosal immune response [22,23].

By the increase of the level of sIgA after probiotics' administration in patients with burns, it was expected that the intestinal immunity system would increase; thus, bacterial translocation would be reduced. The mortality and morbidity level of burns' patients would also reduce [24].

\section{CONFLICTS OF INTEREST}

All authors have none to declare.

\section{REFFERENCES}

1. Jones WG $2^{\text {nd }}$, Minei JP, Barber AE, Rayburn JL, Fahey TJ $3^{\text {rd }}$, Shires GT $3^{\text {rd }}$, et al. Bacterial translocation and intestinal atrophy after thermal injury and burn wound sepsis. Ann Surg 1990;211:399-405.

2. Sanyal SC. Microbiology of septicaemia in burn patients. Ann Burn Fire Disaster 1998;11:1-4

3. Murray C, Hospenthal DR. "Burn Wound Infections". Emedicine; 2008. Available from: http://www.emedicine.medscape.com/article/213595overview. [Last accessed on 2018 Apr 14].

4. Muster AM. In: Baue AE, Faist E, Fry DE. Multiple Organ Failure, Pathophysiology, Prevention and Therapy. New York. Springer; 2000.

5. Wiest R, Garcia-Tsao G. Bacterial translocation (BT) in cirrhosis. Hepatology 2005;41:422-33.

6. Chadwick RW, George SE, Claxton LD. Role of the gastrointestinal mucoda and microflora in the bioactivation of dietary and environmental mutagens or carcinogens. Drug Metab Rev 1992;24:425-92.

7. Gun F, Salman T, Gurler N, Olgac V. Effect of probiotic supplementation on bacterial translocation in thermal injury. Surg Today 2005;35:760-4.

8. Grewal HM, Karlsen TH, Vetvik H, Ahrén C, Gjessing HK, Sommerfelt $\mathrm{H}$, et al. Measurement of specific igA in faecal extracts and intestinal lavage fluid for monitoring of mucosal immune responses. J Immunol Methods 2000;239:53-62.
9. Perdigón G, Fuller R, Raya R. Lactic acid bacteria and their effect on the immune system. Curr Issues Intest Microbiol 2001;2:27-42.

10. Moenadjat Y. Systemic inflammatory response syndrome (SIRS) dan multi system organ dysfunction syndrome (MODS) pada luka bakar. In: Penanganan Luka Bakar. Surabaya: Airlangga University Press; 2006. p. 27-44.

11. Noer MS. Penanganan Luka Bakar Akut. In: Penanganan Luka Bakar. Surabaya: Airlangga University Press; 2006. p. 3-22.

12. Fonseca J. Burn Wound Infections. Retrieved from Drugs and Diseases, Infectious Disease; 2016. Available from: https://www.emedicine. medscape.com/article/213595-overview. [Last accessed on 05 January 2019].

13. Church D, Elsayed S, Reid O, Winston B, Lindsay R. Burn wound infections. Clin Microbiol Rev 2006;19:403.

14. Cakir B, Yegen B. Systemic responses to burn injury. Turk J Med Sci 2004;34:215-26

15. Mayer L. Mucosal immunity. Pediatrics 2003;111:1595-600.

16. Mestecky J, Elson CO. Peyer's patches as the inductive site for IgA responses. J Immunol 2008;180:1293-4.

17. Belcher HJ. Immunological responses. In: Settle JA, editor. Principles and Practice of Burns Management. New York: Churchill Livingstone; 1996. page 163-76.

18. Cebra JJ. Influences of microbiota on intestinal immune system development. Am J Clin Nutr 1999;69:1046S-1051S.

19. Pitono S, Subijanto MS, Suhartono TP, Judajana FM. Gangguan Sistem Imun Mukosa Intestinal. Surabaya, Seri Gramik: Immunoglobulin Mukosa; 2003.

20. Amansec SG. Role of Resistant Starch and Probiotics in Colon Inflammation. Sydney: The University of New South Wales; 2005.

21. Fuller R. Probiotics in human medicine. Gut 1991;32:439-42

22. Woof JM, Mestecky J. Mucosal immunoglobulins. Immunol Rev 2005;206:64-82.

23. Judarwanto W. Imunologi Mukosa Saluran Cerna; 2008. Available from: http://www.alergianak.bogspot.com. [Last accessed on 2010 Feb 10].

24. Arturson G. Mecahanism of Injury. In: Settle JA, editor. Principles and Practices of Burns Management. New York: Churchill Livingstone; 1996. p. $61-82$ 